Sains Malaysiana 50(6)(2021): 1543-1562

http://doi.org/10.17576/jsm-2021-5006-04

\title{
Tillage Systems Affecting Rice-Wheat Cropping System
}

(Sistem Pembajakan Mempengaruhi Sistem Tanaman Padi-Gandum)

\author{
Rafi QamaR*, Atique Ur Rehman, Hafiz Muhammad Rashad Javeed, Abdul Rehman, Muhammad Ehsan \\ SAFDAR, HASNAIN ALI \& SHAKEEL AHMAD
}

\begin{abstract}
Rice-wheat production is an essential component of cropping systems in the Indus-Ganga Plains (IGP) which play a pivotal role in food security of south Asia. These crops are being cultivated on an area of about $13.5 \mathrm{M}$ ha of South Asia. In rice-wheat cropping system, the major reason for lower wheat grain yield is use of unwise tillage practices during wheat seedbed preparation, cultivation of late maturing rice varieties, water shortage, labor shortage, high cost of fertilizers and poor crop management practices. Resource-conserving technology improves the sustainability and productivity of wheat, which ultimately increase the farmer's livelihood and reduce poverty. Tillage plays an important role in agricultural operation for soil manipulation to optimize the crop productivity. Different tillage systems are being practiced for wheat production in rice-wheat cropping systems including intensive tillage system, conventional and deep tillage, conservation tillage that consisting of minimum tillage, ridge tillage, and no-till or zero tillage system. Zero tillage gives more accessible and efficient planting system that ensures timely wheat cultivation, cut off the tillage operation, better crop residue management that ultimately minimize the cost of production and keeps environment clean. Operational costs for wheat sowing are 50-60\% lower with zero tillage (ZT) sowing than with conventional sowing. The cost saving effect is the main reason for the spread of zero tillage technology in rice-wheat system. Current paper presented a review of different tillage systems and their effects on soil physical properties, plant available water, soil organic matter and nutrients, rice residues, wheat yield and farmer's economics.
\end{abstract}

Keywords: Rice; rice-wheat system; tillage system effects; wheat; zero tillage

\section{ABSTRAK}

Pengeluaran gandum adalah komponen penting dalam sistem penanaman di Indo-Gangetic Plains (IGP) Asia Selatan yang mempunyai peranan penting dalam keselamatan makanan dunia. Tanaman ini diusahakan di kawasan seluas kirakira 13.5 M ha di Asia Selatan. Dalam sistem penanaman gandum padi, alasan utama penurunan hasil gandum adalah penggunaan amalan penanaman yang tidak bijak semasa penyediaan benih gandum, penanaman varieti padi yang sudah matang, kekurangan air, kekurangan tenaga kerja, kos baja yang tinggi dan amalan pengurusan tanaman yang buruk. Teknologi penjimatan sumber meningkatkan kelestarian dan produktiviti gandum, yang akhirnya meningkatkan penghidupan petani dan mengurangkan kemiskinan. Pembajakan mempunyai peranan penting dalam operasi pertanian untuk manipulasi tanah untuk mengoptimumkan produktiviti tanaman. Sistem penanaman yang berlainan dipraktikkan untuk produksi gandum dalam sistem penanaman gandum padi termasuk sistem pengolahan intensif, penanaman konvensional dan dalam penggarapan konservasi yang terdiri daripada pengolahan minimum, penanaman rabung dan sistem penanaman tanpa penanaman atau sifar. Tanaman sifar menghasilkan sistem penanaman yang lebih mudah diakses dan cekap yang memastikan penanaman gandum tepat pada masanya, memotong operasi penanaman, pengurusan sisa tanaman yang lebih baik yang akhirnya meminimumkan kos pengeluaran dan menjaga kebersihan persekitaran. Kos operasi untuk semaian gandum adalah 50-60\% lebih rendah dengan semaian sifar pembajakan (ZT) daripada semaian konvensional. Kesan penjimatan kos adalah sebab utama penyebaran teknologi penanaman sifar dalam sistem gandum. Kertas ini membentangkan kajian mengenai sistem pengolahan yang berbeza dan kesannya terhadap sifat fizikal tanah, air yang ada pada tanaman, bahan organik tanah dan nutrien, sisa beras, hasil gandum dan ekonomi petani.

Kata kunci: Gandum; kesan sistem pembajakan; padi; sawah; sistem padi-gandum 


\section{INTRODUCTION}

Rice-wheat production area of Pakistan, India, Nepal, and Bangladesh have immense natural resources, productive soil, variant climatic conditions, and good quality water, which favors multiple-cropping systems. Rice-wheat production system has significant role in providing $8 \%$ staple grain of the world's population (Ladha et al. 2003; Timsina \& Connor 2001). In Indian-subcontinent, the total area under rice-wheat cropping system is $13.5 \mathrm{M}$ ha (Ladha et al. 2000). South Asian countries like India, Pakistan, Bangladesh, and Nepal have distinct area and share in rice-wheat cropping system (Timsina \& Connor 2001)
(Table 1). An overview of rice-wheat system in Pakistan is depicted in Figure 1. In Pakistan, wheat is grown during winter season starting from November and ends in April. This season have distinct feature of cool and dry conditions, December and January being the coldest months. After the harvest of wheat, one-month-old rice nursery is transplanted in the end of June or beginning of July and harvested up to November. Warm humid or semi humid conditions prevail during summer season, which are best suited for rice growth. A summary of agro-meteorological conditions for the last ten years is given in Figure 2.

TABLE 1. Area under rice-wheat system in South Asia

\begin{tabular}{|c|c|c|c|c|c|}
\hline \multirow[t]{2}{*}{ Country } & \multirow[t]{2}{*}{$\begin{array}{l}\text { Area under rice-wheat-based } \\
\text { cropping systems (million ha) }\end{array}$} & \multicolumn{2}{|c|}{$\begin{array}{l}\text { Share of crop area under rice- } \\
\text { wheat-based cropping system } \\
(\%)\end{array}$} & \multicolumn{2}{|c|}{ Contribution of rice and wheat (\%) } \\
\hline & & Rice & Wheat & $\begin{array}{l}\text { Total cereal } \\
\text { production }\end{array}$ & $\begin{array}{c}\text { Total national calorie } \\
\text { intake }\end{array}$ \\
\hline India & 10.3 & 23 & 40 & 85 & 60 \\
\hline Pakistan & 2.2 & 72 & 19 & 92 & 62 \\
\hline Bangladesh & 0.5 & 5 & 85 & 100 & 94 \\
\hline Nepal & 0.6 & 35 & 84 & 71 & 63 \\
\hline
\end{tabular}

Source: Adapted from Timsina and Connor (2001)

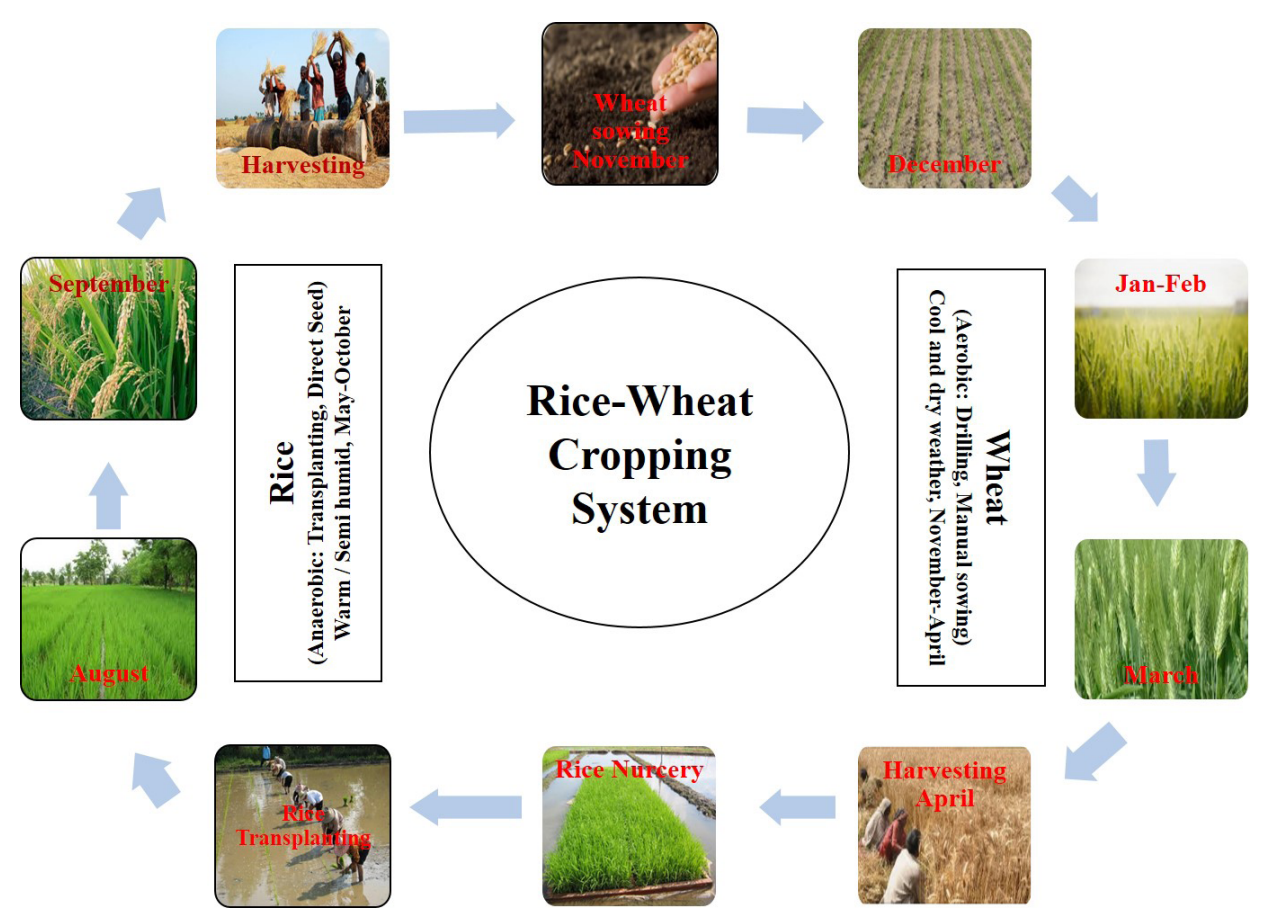

FIGURE 1. An overview of rice-wheat system in Pakistan 


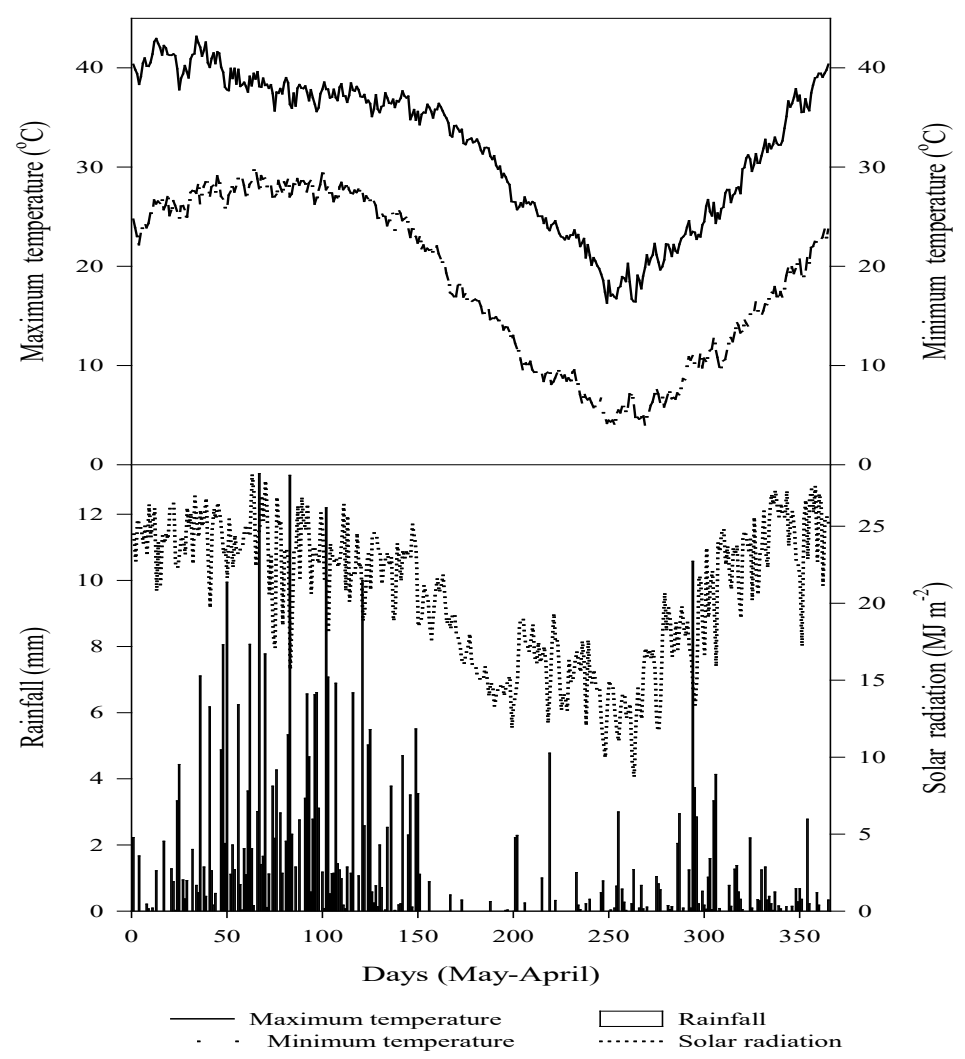

FIGURE 2. Weather conditions prevailing during rice-wheat cropping system (10-year mean)

In Pakistan, rice-wheat occupies central position in regulating agricultural policies and dominates all agronomic crops in the form of total acreage and yield (Ahmad et al. 2015). In rice-wheat system, rice nursery is transplanted to puddled field. During puddling, soil is saturated by flooding water (4-6 inches), plowed extensively the supersaturated soil and then plowing at relatively lower water depths (Figure 3). Rice is generally harvested mechanically by combine harvester, which leaves rice stubbles in the field. The handling of stubbles requires several tillage operations, which ultimately delay the planting of wheat crop. Wheat is the main staple food in Pakistan, which is grown under conventional tillage in post-harvest puddled rice fields (Figure 3). In conventional system, seedbed for sowing is prepared by 3-4 ploughings in previously paddy fields. Although it is good practice for sowing of wheat but due to extensive tractor passage, lower soil layers become more compacted which is problematic during wheat growth (Figure 3). However, ZT on such fields is helpful in improving soil structure (Figure 3). The late maturing rice varieties, unwise tillage operations, lack of moisture and unavailability of fuel (Figure 4) results in delayed wheat sowing (Hobbs $\&$ Gupta 2003). Conventional tillage not only degrades the soil structure and water resources, but also affects the sustainability of the agricultural production (Gupta et al. 2003; Kumar \& Yadav 2001). Conventional plowing at the same depth creates subsoil compaction (Kukal \& Aggarwal 2003). Subsoil compaction (e.g. increased bulk density) can be decreased by deep plowing instead of shallow plowing (Håakansson 2005). Higher soil bulk density reduced the soil porosity, restricted root growth, concomitant poor plant growth and yield, which are the main negative impacts of soil compaction (Hamza \& Anderson 2005). 
Rice

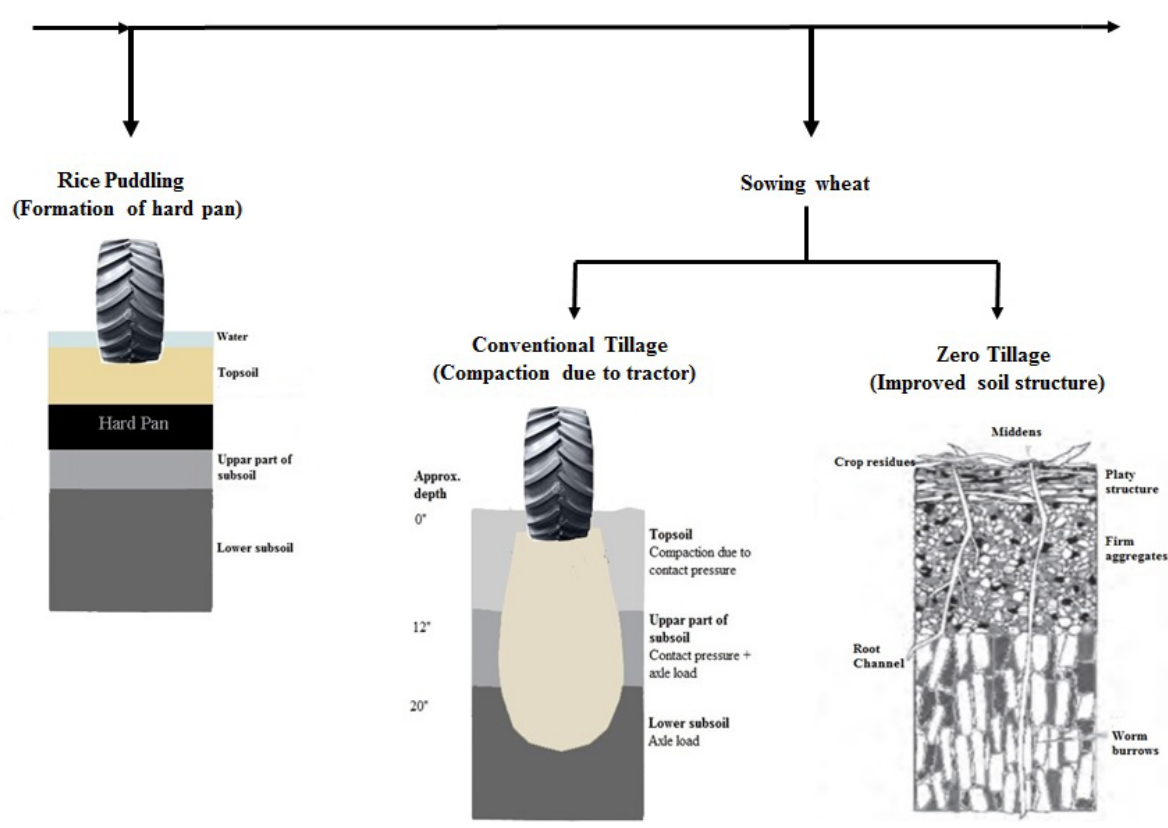

FIGURE 3. Schematic illustration of tillage affects in rice wheat system

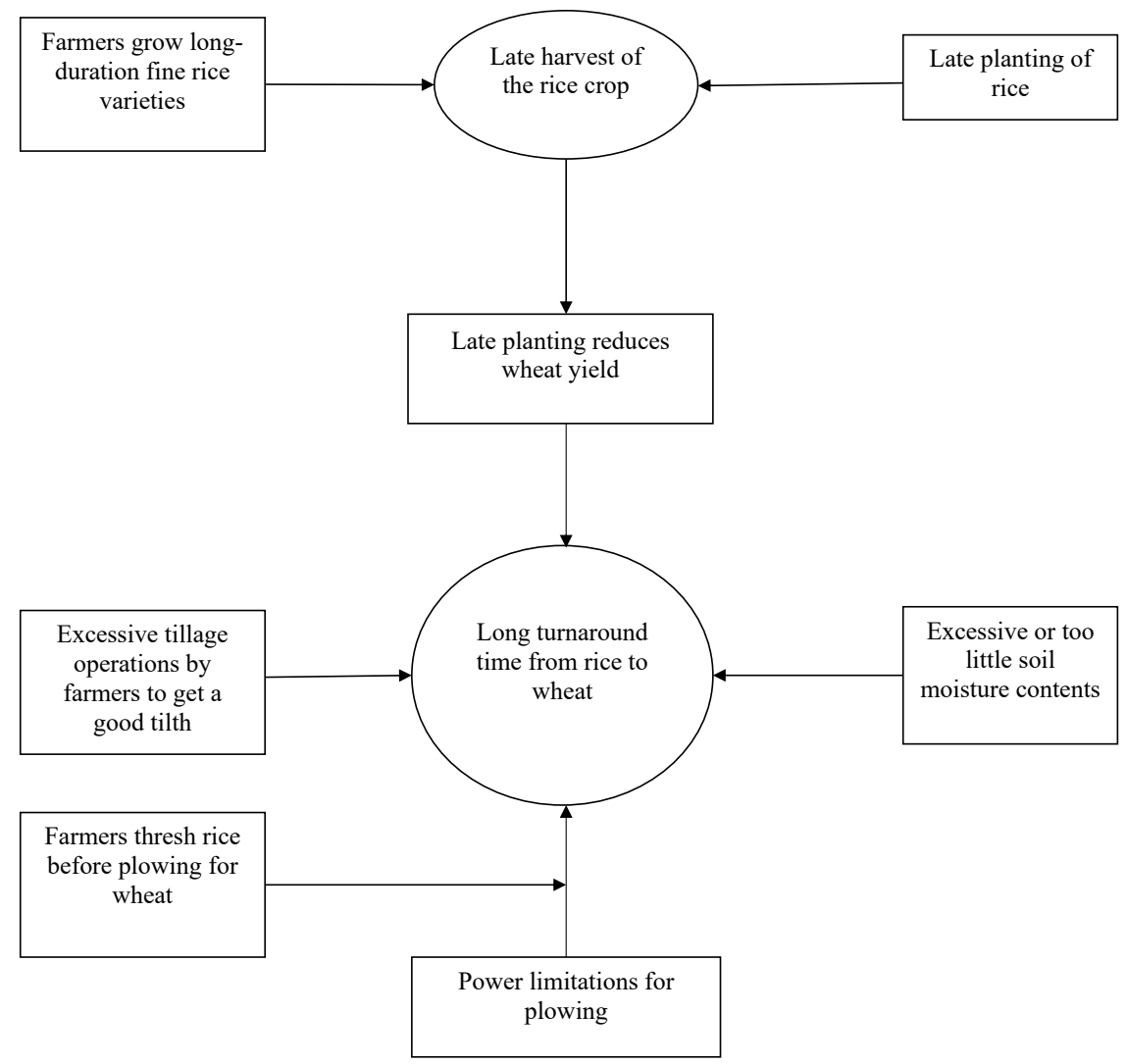

FIGURE 4. The most common causes of late wheat planting following the rice harvest Source: Hobbs and Gupta (2003) 
In rice-wheat production system, wheat yield can be increased by managing input resources and by overcoming the problem of delayed planting through conservation tillage practices. The no-till system is a specialized type of conservation tillage consisting of a one-pass planting and fertilizer operation in which the soil and the surface residues are minimally disturbed (Gupta et al. 2003). Conservation tillage is mainly used to overcome soil erosion, maximize vegetative cover on the land, increase soil organic matter, energy and water footprints, and sustain farm economics (Brula 2002; Kumar \& Yadav 2001; Lithourgidis et al. 2005). Conservation agriculture is one of the best ways to overcome the problems of water shortage and soil fertility.

Zero-tillage is the conservation tillage, which is well known as zero-till, no-till, direct seeding and direct drilling (Erenstein et al. 2008a). No-till techniques have been successfully applied on an area of more than $111 \mathrm{M}$ ha worldwide (Derpsch et al. 2010). Continuous use of reduced or no-till practices substantially improves the net profitability of crop production (Verch et al. 2009). The yield of zero-till wheat is equal to or even higher than the yields produced by conventional tillage (Hemmat \& Eskandari 2004; McMaster et al. 2002). However, no-till wheat yields are often affected by poor crop stand due to soil compaction, anoxic conditions, and immobilization of nitrogen (Alvarez \& Steinbach 2009; Rahman et al. 2005). Similarly, wheat yield responses under reduced tillage with previous crop residues are inconsistent, because of immobilization of nitrogen, low soil temperatures, high moisture content, and transitional cropping environment (Carr et al. 2003; Hemmat \& Eskandari 2004). Fertilizer application with reduced and no-till seeding requires careful attention in order to optimize efficiency of fertilizer use by crops (Selles et al. 1999). Crop residues have an excess amount of organic nitrogen, which is not available for plant growth. This organic nitrogen is only available for plant growth after the process of mineralization, which is carried out by microorganisms (Lupwayi et al. 2006). No-till could significantly improve the supply of soil nitrogen and phosphorus by reducing their losses and with controlled soil erosion and runoff (Xu et al. 2006).

Soil nutrients increased significantly over time with crop residues incorporation (Zhang et al. 2005). Tillage and crop residues have critical effects on plant growth and yield. Accumulation of crop residues on surface with zero tillage improves soil health and increases crop yields (Rafi et al. 2012). Zero tillage (ZT) wheat cultivation generates an additional profit in terms of high yield, lower the fuel and labor charges and gave greater benefit cost ratios (BCR) than other tillage systems. The adoption of
ZT technology is thus helpful in increasing farmer's profit, improving his livelihood and eventually reduces poverty by reduction in cost of production and increase in yield. The technology is gaining attention among the farmers relative to conventional tillage $(\mathrm{CT})$.

There are not much reported studies on the conservation tillage and crop residues management strategies in rice-wheat cropping system in Pakistan. The present review was planned with objective viz. to evaluate the role of various tillage practices on crop residues management in post-harvest rice fields, to determine the effects of tillage systems on soil physical properties and wheat yields and to assess the best planting method for wheat cultivation in rice-wheat cropping system.

\section{TILLAGE SYSTEMS IN RICE WHEAT SYSTEM \\ COMPARATIVE EFFICACY OF TILLAGE SYSTEMS}

Conventional tillage has better soil aeration, field workability, and less soil compaction, which maximize seed germination and plant establishment than zero tillage (Licht \& Mahdi 2005). Zero tillage is one of the most widely adopted technology for timely planting of crops, controlling soil erosion, and reducing the cost of operations in IGP (Erenstein et al. 2008a). Wheat after rice sown by zero tillage generates an additional profit in terms of higher yield and BCR in most of studies (Table 2) than conventional methods (Younis et al. 2006). The adoption of ZT increases farmer's profit, improve their livelihood, and eventually reduces poverty (Bakhsh et al. 2005). Zero tillage technology is becoming attractive and spreading among the farmers due to its lower cost of production and higher yield than conventional tillage (De Vita et al. 2007). Deep tillage and use of the happy seeder (zero tillage drill) improve the wheat yield than conventional tillage and zone disc tiller under irrigated wheat after puddled rice field (Rafi et al. 2012) (Figure $5)$. The beneficial effect of ZT is not only the reduction in the water loss (e.g. evaporation) but it also increases soil moisture availability and decreases tractor time with an average of $8.9 \mathrm{~h} \mathrm{ha}^{-1}$ or an average $81 \%$ and diesel use in the range of $15-601 \mathrm{ha}^{-1}$ or an average $81 \%$ saving in the form of farm energy consumption (Table 3) (Erenstein \& Laxmi 2008). Zero tillage reduces the soil erosion that is helpful in controlling soil structural degradation (Figure 6) (Tabatabaeefar et al. 2009). Soil organic carbon content depends on the soil depth, which is influenced by the type of tillage systems (Figure 7). Soil zero tillage has greater organic carbon concentration only at the surface layer but not for the whole soil profile compared with the chisel and mouldboard tillage system (Deen \& Kataki 2003). Deen 
and Kataki (2003) studied the impact of conservation tillage practices on carbon sequestration. They concluded that changes in the soil organic carbon (SOC) as influenced by tillage are more noticeable under long-term rather than short-term tillage practices. They analyzed the organic carbon status of soils sampled at depth of 0 to $60 \mathrm{~cm}$. Zero tillage was compared to conventional tillage practices with moldboard and chisel plow. The SOC concentration was found dependent on the depth of tillage operation and the higher SOC at 0-5, 5-10, and 20-40 cm depth was recorded with zero tillage followed by chisel and moldboard tillage. In conclusion, ZT practices increased $36-62 \%$ SOC concentration compared to conventional tillage operations but it was only in the surface layer and not in the entire soil profile. Thus, more soil organic carbon contents present within depths of $0-5 \mathrm{~cm}$ in ZT. The concentration of SOC and nitrogen decreases with increasing the soil depth. Similarly, phosphorus $(20 \%)$ and potassium $(30 \%)$ were higher at $0-20 \mathrm{~cm}$ layer in $\mathrm{ZT}$, which was much more as compared to under conventional tillage (López-Fando \& Pardo 2009).

TABLE 2. Tillage systems effects on gross margin and benefit cost ratio

\begin{tabular}{|c|c|c|c|c|}
\hline \multirow[b]{2}{*}{ Source } & \multicolumn{2}{|c|}{$\mathrm{CT}$} & \multicolumn{2}{|c|}{ NT } \\
\hline & $\begin{array}{c}\text { Gross margin Rs } \\
\mathrm{ha}^{-1}\end{array}$ & Benefit cost ratio & $\begin{array}{c}\text { Gross margin Rs } \\
\text { ha- } 1\end{array}$ & Benefit cost ratio \\
\hline Bakhsh et al. (2005) & 13731 & 1.81 & 16815 & 2.28 \\
\hline Iqbal et al. (2002) & 351370 & 1.16 & 410830 & 1.76 \\
\hline Sarwar and Goheer (2003) & 13794 & 1.12 & 17145 & 1.68 \\
\hline Ozpinar (2006) & 9760 & - & 1760 & - \\
\hline Erenstein et al. (2008b) & 46240 & 1.37 & 47840 & 1.27 \\
\hline Tahir et al. (2008) & 27256 & 2.19 & 29286 & 2.11 \\
\hline Gill (2006) & 7258 & - & 7963 & - \\
\hline
\end{tabular}

TABLE 3. Tractor time and diesel use in ZT and CT in different regions of IGP

\begin{tabular}{lcccccc}
\hline & \multicolumn{3}{c}{ Tractor time $\mathrm{h} \mathrm{ha}^{-1}$} & \multicolumn{3}{c}{${\text { Fuel use } 1 \mathrm{ha}^{-1}}^{\text {Source }}$} \\
\cline { 2 - 7 } & $\mathrm{ZT}$ & $\mathrm{CT}$ & Saving (\%) & ZT & CT & Saving (\%) \\
\hline Yaduraju and Mishra (2002) & 2.25 & 11.2 & 80 & 12.5 & 33 & 62 \\
Sharma et al. (2002) & 1.6 & 9.4 & 83 & 6 & 65 & 91 \\
Erenstein et al. (2008a) & 2.22 & 8.19 & 73 & 12.1 & 48 & 75 \\
Singh and Sharma (2005) & 2 & 9.5 & 79 & 7.1 & 48.8 & 86 \\
Sinha et al. (2005) & 2.3 & 11.5 & 80 & 11 & 54.5 & 80 \\
Rautaray (2005) & 3.2 & 10.8 & 70 & 11.3 & 34.6 & 67 \\
\hline
\end{tabular}

Source: Erenstein and Laxmi (2008) 


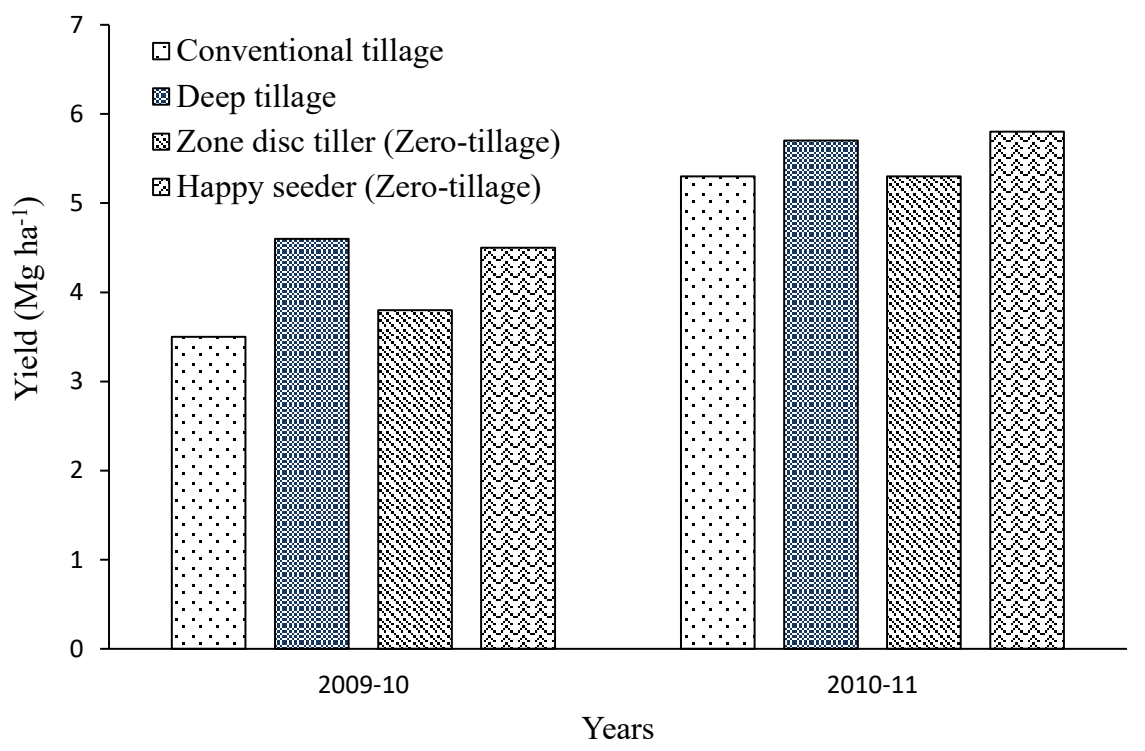

FIGURE 5. Yield comparison between different tillage systems Source: Rafi et al. (2012)

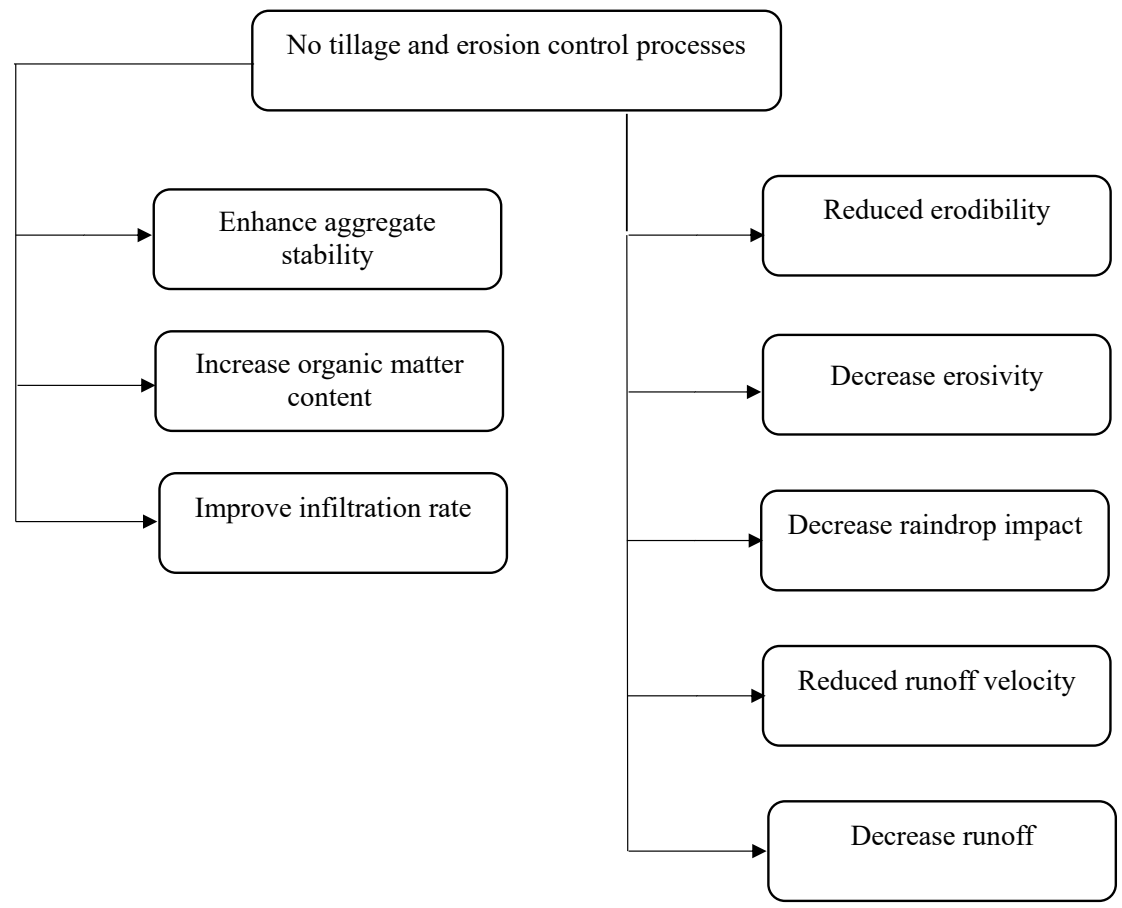

FIGURE 6. Mechanisms and processes in erosion control by no-tillage system 


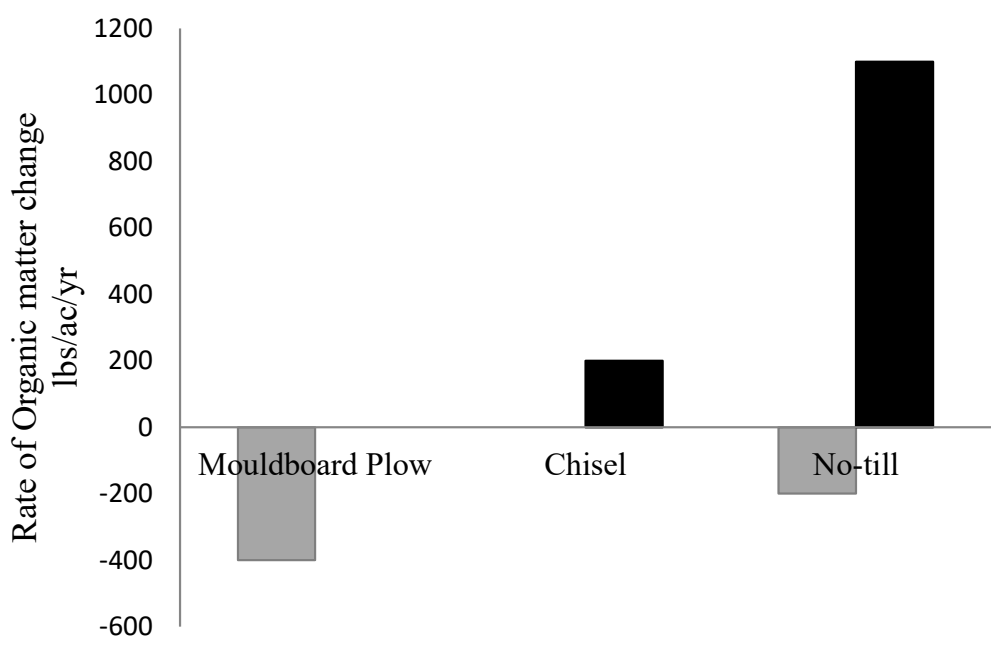

FIGURE 7. Tillage system effects on soil organic matter change

Source: Eileen Kladivko, Purdue University

\section{TILLAGE SYSTEM AND SOIL PHYSICAL PROPERTIES}

Soil physical environment is important for maintaining sustainable agronomic production. Tillage operation alters the soil physical properties (Table 4) and improves the soil conditions for optimal crop emergence and yield (Boydaş \& Turgut 2007). Different tillage implements and operational variables may affect soil physical properties like mean weight, diameter, moisture content, penetration resistance, bulk density, and emergence rate index. Aggregate stability, water infiltration rate, soil bulk density and cone penetrometer penetration resistance were higher under limited tillage systems than under plow tillage. Zero tillage has fast drainage, more macro pores, greater soil water movement and infiltration rate, aggregate stability, bulk density and cone penetration resistance than conventional tillage system (Alvarez \& Steinbach 2009). Martínez et al. (2008) said that zero-tillage systems affected soil properties depending on the soil, climate, and the time since its implementation. In heavy no-tilled soil a surface compacted layer was commonly found which could affect root growth and soil water infiltration that might be overcome by surface organic carbon. The zero tillage had fast drainage due to the presence of more macro pores, soil particle density and high water infiltration rates. Tillage treatments did not significantly affect bulk density and yield. Moreover, zero tillage minimized the detrimental effects on soil erosion. Organic matter content and pore connectivity in the upper soil layer increased by the use of long-term zero-till system (Cavalieri et al. 2009). In rice-wheat system, $\mathrm{ZT}$ along with residue retention on soil surface is a sustainable technology for obtaining higher yields due to improvement in soil organic matter and availability of water than conventional farming practices. Zero tillage is the only way to maintain the soil productivity by avoiding the intensive use of tillage machinery (Fabrizzi et al. 2005). Zero tillage along with residue retention has lower values of soil bulk density, penetration resistance and infiltration rate than conventional tillage (Jat et al. 2009). Soil bulk density and penetration resistance are decreased by increasing the soil disturbance (Osunbitan et al. 2005; Pedrotti et al. 2005). However, the soil bulk density was not a suitable indicator for soil quality (Logsdon \& Karlen 2004). In rice-wheat, cropping system unwise tillage operation deteriorated the soil structure.

An important advantage of ZT to the improvement of soil structure, however, it increased the soil compaction, which has negative impact on crop growth (Ferreras et al. 2000). The continuous use of tillage operations at the same depth also cause sub-soil compaction that affects the soil porosity, bulk density and plant root proliferation. Due to these reasons, root length and growth was found dependent on the tillage systems (Figure 8) (Rafi et al. 2012). These soil physical properties also affect nutrients availability in the soil (Ahmad et al. 2009). Crop residue retention with $\mathrm{ZT}$ enhances the soil physical environment under rice-wheat cropping system (Sharma \& Bhushan 2001). Czyż and Dexter (2008) stated that ZT with crop residues create more-friendly environment for improving 
soil physical properties, soil stability, and water content than conventional tillage. They used two methods of tillage system viz. traditional and reduced along with wheat straw mulch and measured particle size distribution (hydrometer method), soil bulk density and water content.

They concluded that reduced tillage resulted in increased soil stability, bulk density, and water content in comparison with traditional tillage. The reduced tillage system created a more-friendly environment for soil physical properties particularly soil stability than the conventional system. Bai et al. (2008) reported that controlled traffic zero and minimum tillage management with residue cover is a better solution to control erosion and other soil degradation problem. They compared conventional tillage with controlled traffic zero tillage and reported that soil bulk density, total porosity, macroporosity and mesoporosity increased at the expense of microporosity. Readily available water content and saturated hydraulic conductivity were greater in controlled traffic treatments.

TABLE 4. Tillage systems effects on soil bulk density, water content and total porosity

\begin{tabular}{|c|c|c|c|c|c|c|}
\hline \multirow[t]{2}{*}{ Source } & \multicolumn{2}{|c|}{ Bulk density $\left(\mathrm{g} \mathrm{cm}^{3}\right)$} & \multicolumn{2}{|c|}{$\begin{array}{l}\text { Volumetric water content } \\
\qquad\left(\mathrm{mm} \mathrm{cm}^{-1}\right)\end{array}$} & \multicolumn{2}{|c|}{$\begin{array}{l}\text { Total porosity }\left(\mathrm{cm}^{3}\right. \\
\left.\mathrm{cm}^{-3}\right)\end{array}$} \\
\hline & $\mathrm{CT}$ & NT & $\mathrm{CT}$ & NT & $\mathrm{CT}$ & NT \\
\hline Gangwar et al. (2006) & 1.62 & 1.66 & - & - & - & - \\
\hline Gangwar et al. (2004) & 1.59 & 1.68 & - & - & - & - \\
\hline López-Fando and Pardo (2009) & 1.57 & 1.61 & - & - & - & - \\
\hline Fernández-Ugalde et al. (2009) & 1.58 & 1.78 & - & - & - & - \\
\hline Rafi et al. (2012) & 1.46 & 1.55 & 0.7 & 1.4 & 0.47 & 0.43 \\
\hline Basamba et al. (2006) & 1.28 & 1.42 & 1.2 & 1.7 & 0.52 & 0.50 \\
\hline Malecka et al. (2012) & 1.39 & 1.69 & 1.2 & 1.7 & - & - \\
\hline Meenakshi (2010) & 1.44 & 1.46 & 1.9 & 1.9 & - & - \\
\hline Tripathi et al. (2007) & 1.53 & 1.54 & - & - & - & - \\
\hline Veiga et al. (2008) & 1.03 & 1.10 & - & - & 0.61 & 0.60 \\
\hline
\end{tabular}

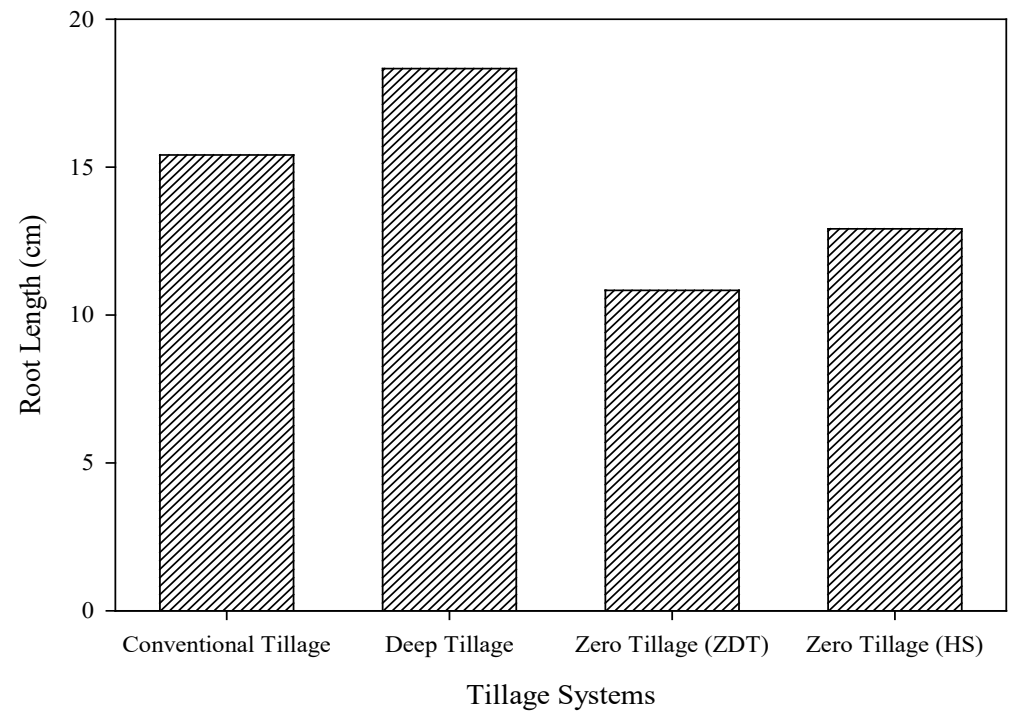

FIGURE 8. Different tillage systems effect on root length (data combined over 2009-2010 and 2010-11). ZDT=Zone disk tiller (zero tillage drill), HS=Happy seeder (zero tillage drill) Source: Rafi et al. (2012) 


\section{TILLAGE SYSTEM AND SOIL MOISTURE CONTENT}

In scenario of changing climatic conditions, the significance of soil and water conservation for crop production is well understood. In this contest, role of conservation tillage practices like zero and minimum tillage becomes of vital importance. Zero tillage improved water retention, transmission and soil strength by increasing soil aggregation, reducing runoff and improving soil hydrological properties as compared to conventional tillage practices (Abid \& Lal 2008). Different irrigation sources are used in rice-wheat cropping areas of Punjab, Pakistan (Ahmad et al. 2004) (Figure 9). In this system, majority of farmers are using canal water which is relatively less available in winter season or during wheat period. In most of the cases, initial soil moisture contents required for germination of wheat seed are not enough due to lack of water during this season. As rice is conventionally grown in puddled field require a huge amount of water, residual moisture contents from rice fields will be helpful to solve the problem for subsequent wheat crop. Crop residues deposition on the soil surface acts as mulch that improves the water infiltration and reduce the water loss by evaporation (Shipitalo et al. 2000). Zero tillage along with crop residue retention enhanced the water use efficiency and soil water content that ultimately increase the crop yield (Table 5). In deep tillage, water storage was more at 50 to $100 \mathrm{~cm}$ soil depth compared with ZT while the water consumption reduces in sub-soiling at 0 to $50 \mathrm{~cm}$ and increases in 50 to $100 \mathrm{~cm}$ soil depth (Qingjie et al. 2009). Sub-soiling increased the yield by $18.3 \%$ and the water use efficiency by $16.8 \%$. Sub-soiling under NT (no tillage) is the effective rotation tillage to contain more soil moisture and improve water use efficiency ( $\mathrm{Li}$ et al. 2008). Conservation tillage improved soil productivity and water conservation. It is effective method for improving crop yields and water use efficiency (Jin et al. 2007). Conservation tillage along with residue retention stored more soil water content and enhanced water use efficiency that had positive effect on crop yield. Similarly, ZT with crop residues has maximum soil organic matter contents that improves the soil pore spaces distribution and enhances the water availability in the soil (Bescansa et al. 2006).

TABLE 5. Tillage systems effects on water use efficiency $\left(\mathrm{kg} \mathrm{ha}^{-1} \mathrm{~mm}^{-1}\right)$

\begin{tabular}{lll}
\hline \multicolumn{1}{c}{ Source } & \multicolumn{2}{c}{ Water use efficiency $\left(\mathrm{kg} \mathrm{ha}^{1} \mathrm{~mm}^{-1}\right)$} \\
& CT & NT \\
\hline Khaledian et al. (2010) & 5.5 & 2.8 \\
Mohammad et al. (2006) & 5.4 & 5.3 \\
Rafi et al. (2012) & 9.7 & 12.6 \\
Mrabet et al. (2000) & 11.3 & 12.4 \\
Sarwar and Goheer (2003) & 13.8 & 18.6 \\
Mrabet (2002) & 5.7 & 6.1 \\
\hline
\end{tabular}

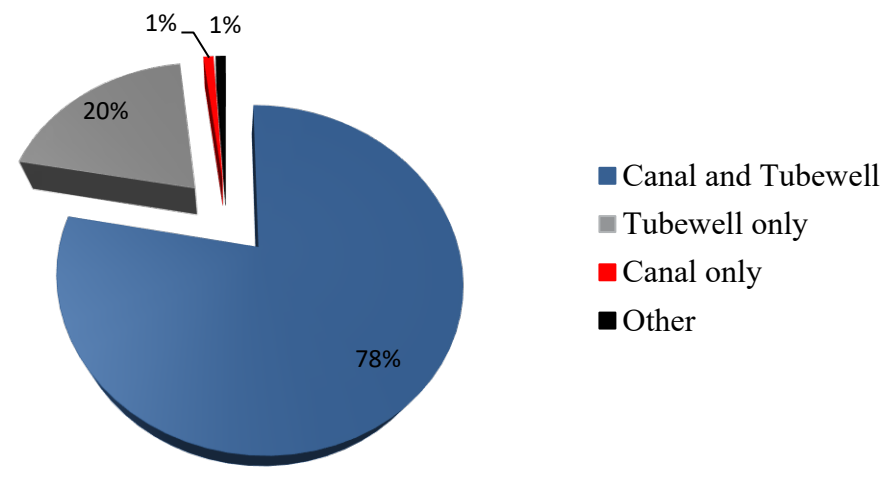

FIGURE 9. Source of irrigation in rice-wheat zone of the Punjab, Pakistan 


\section{TILLAGE SYSTEM AND SOIL ORGANIC MATTER CONTENT}

Conventional tillage increases the crop residues turn over and reduces the organic matter concentration due to incorporation of crop residues with soil. However, CT release soil carbon to the atmosphere and contributes to soil erosion, which results in a loss of organic matter and long-term ability of the soil to sequester carbon. The ZT and conservation tillage have substantial effect on the soil organic matter, nitrogen and exchangeable cations when compared with CT (Balesdent et al. 2000). In ZT, more organic matter accumulation near the soil surface, which is suitable for improving soil physical and chemical properties and crop yields (Thomas et al. 2007). Soil organic carbon and nitrogen are mostly present in macroaggregates and their proportion is higher in $\mathrm{ZT}$ than $\mathrm{CT}$ (Sundermeier et al. 2011). Therefore, ZT sequestered more soil organic carbon and soil organic nitrogen on surface soil. The soil carbon losses occur more if plowing is done for more than one year. Zero tilled soil sequestered more than 67 to $512 \mathrm{~kg} \mathrm{C}^{-1}$ per year than conventional tilled soil (McConkey et al. 2003). The varying level of organic matter contents at different soil surface depth under ZT was one of the key indicators for soil quality determination. Soil organic carbon accumulation at soil surface reduced the erosion, enhanced the infiltration of water and conserved soil nutrients. In semi-arid region, the process of mineralization was high and lack of crop residues decreased the soil fertility. Zero tillage system has higher rate of soil organic matter due to more carbon contents than in MT and CT (Figure 10) (Hernanz et al. 2009). Soil organic carbon has beneficial effects on crop and soil productivity that attain by placing the crop residues on soil surface and incorporation. Crop residue at soil surface was lost before sequestered as SOC. Therefore, stubbles incorporation is only the beneficial way for soil organic carbon sequestration (Liu et al. 2009). Zero tillage has greater SOC stocks at $0-5 \mathrm{~cm}$ depth than the CT but not at 0-20 cm soil depth (Table 6) (Šimon et al. 2009). In sustainable agriculture, NT was the key tool, which affected the SOC dynamics. There is a close relationship between SOC concentration and CEC due to high negative charge and with a high CEC, enhanced SOC concentration was observed (De Moraes Sa et al. 2009). Soil organic carbon and nitrogen stocks decrease rapidly during few months after plowing on area of several years of conservation tillage (zero tillage) under temperate climate (Koch \& Stockfisch 2006).

TABLE 6. Tillage systems effects on soil organic matter content $\left(\mathrm{g} \mathrm{kg}^{-1}\right)$

\begin{tabular}{|c|c|c|c|c|c|}
\hline \multirow{2}{*}{ Source } & \multicolumn{5}{|c|}{ Soil organic matter $\left(\mathrm{g} \mathrm{kg}^{-1}\right)$} \\
\hline & Soil depth $(\mathrm{cm})$ & $\mathrm{CT}$ & DT & RT & NT \\
\hline \multirow{2}{*}{ Malecka et al. (2012) } & $0-5$ & 8.07 & - & 9.55 & 10.18 \\
\hline & $10-20$ & 7.97 & - & 7.60 & 7.43 \\
\hline \multirow{2}{*}{ Fernández-Ugalde et al. (2009) } & $0-5$ & 10.17 & - & - & 12.55 \\
\hline & $5-15$ & 9.63 & - & - & 9.68 \\
\hline \multirow{2}{*}{ López-Fando and Pardo (2009) } & $0-5$ & 6.56 & - & 7.35 & 12.39 \\
\hline & $5-10$ & 6.46 & - & 8.01 & 9.59 \\
\hline Khurshid et al. (2006) & - & 7.3 & 8.4 & 8.7 & - \\
\hline Gangwar et al. (2006) & - & 5.0 & - & 5.1 & 5.1 \\
\hline \multirow{2}{*}{ Al-Kaisi et al. (2005) } & $0-15$ & 4.8 & 4.3 & - & 4.0 \\
\hline & $15-30$ & 4.6 & 4.2 & - & 4.5 \\
\hline
\end{tabular}

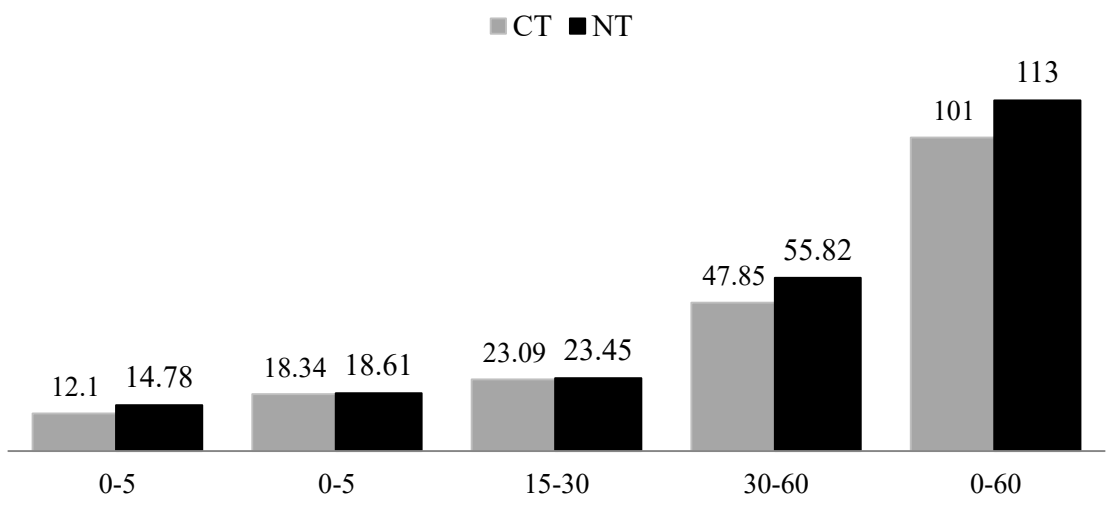

FIGURE 10. Soil organic carbon after 18 years continuous conventional and no-till 


\section{TILLAGE SYSTEM AND SOIL NUTRIENTS}

Soil distribution has significant impact on nutrient dynamics in the soil and extent of nutrient availability was found to be varied with depth of tillage practices (Table 7). However, effect of tillage system was more drastic for phosphorus $(\mathrm{P})$ concentration than nitrogen $(\mathrm{N})$ and potassium $(\mathrm{K})$ concentration. Crop yield is positively related with $\mathrm{N}, \mathrm{P}, \mathrm{K}$, and organic matter concentration while negatively correlated with penetration resistance. Tillage intensity and crop residues have strong effect on $\mathrm{N}$ dynamics which was due to loss of upper soil. Zero tillage is one of the most widely adopted technique to overcome the problems of water shortage and enhanced the soil fertility status by controlling soil erosion. The process of $\mathrm{N}$ mineralization under $\mathrm{ZT}$ reduces the $\mathrm{N}$ losses and enhances the N use efficiency than CT (Van Den Bossche et al. 2009). Similarly, under conservation tillage practices, the accumulation of crop residues at soil surface increased the SOC content and other nutrients concentrations. The $\mathrm{N}$ mineralization is reported higher at upper soil surface with ZT, which consequently increased the crop yield (Salinas-Garcia et al. 2002). Crop residue and less tillage intensity not only reduces the soil erosion but also reduces the N leaching (Sainju et al. 2006). Jacobs et al. (2009) also reported that ZT with crop residue has higher SOC and total $\mathrm{N}$ contents because of soil macro-aggregate stability that protects organic matter in soil. Tillage system has a strong relationship with $\mathrm{N}$ application method, which directly effects on nitrogen use efficiency (NUE), $\mathrm{N}$ uptake, and ultimately crop yield. Zero tillage with V-blade application method improved the NUE and crop yield (Teal et al. 2007). Martin-Rueda et al. (2007) reported that SOC, N, and some other nutrients are strongly influenced by tillage system and higher concentration of nutrients was present at upper soil depths with ZT. In conservation tillage system higher concentration of $\mathrm{N}, \mathrm{P}$ and $\mathrm{K}$ was present at upper soil depths as compared with CT (Table 7) (Fernández et al. 2007). Tillage influenced the nutrient distribution in the soil profile and a more nutrient loss was observed due to intense sub-soiling. Further, the concentrations of $\mathrm{P}, \mathrm{Mg}$ and $\mathrm{Ca}$ were higher at soil surface in ZT than in deep tillage (Bauer et al. 2002). In ZT, higher SOC and $\mathrm{N}$ are present at 4 to $8 \mathrm{~cm}$ soil depth and reduced below $12 \mathrm{~cm}$ (Zibilske et al. 2002). Similarly, tillage affects the organic and inorganic $\mathrm{P}$ distribution in the rhizosphere. It was observed that under no-till or ZT, the total required $P$ was much less than $C T$ which was due more availability of residual P. It is reported that the availability of residual $\mathrm{P}$ was increased up to $30 \%$ with no-till or ZT. The availability of $\mathrm{P}$ was controlled by organic $\mathrm{P}$, which was the larger part of the total $\mathrm{P}$ (Zamuner et al. 2008). Soil aggregation has a direct effect on the $\mathrm{P}$ dynamics in the soil profile. Higher soil aggregation increased the $P$ sequestration and storage in organic pool. Intensive cultivation decreases the aggregation size, which increases the $P$ accumulation in inorganic fractions (Wright 2009). Conservation tillage had higher contents of SOM than in CT, which increased the availability of $\mathrm{P}$ (Vogeler et al. 2009). Tillage system also has effects on the leaching and surface runoff of $P$. Soil solution contains both organic and inorganic $\mathrm{P}$ and $30 \pm 70 \%$ organic $\mathrm{P}$ is found in mineral soils. Inversion tillage often reduced the phosphate losses. The aggregate size was decreased by secondary tillage, which increased the surface area for P sorption. According to Addiscott and Thomas (2000), tillage increased the organic phosphate mineralization. Nutrient distribution is different under different crop rotation and tillage systems. However, concentration of $\mathrm{N}$ and $\mathrm{K}$ was greater in $\mathrm{ZT}$ than in CT while soil $\mathrm{P}$ concentration was usually less different between two tillage systems (conventional and zero). The concentration of nutrients decreased at deeper soil profile with ZT relative to CT (Lupwayi et al. 2006).

TABLE 7. Effect of tillage systems on soil nutrient dynamics

\begin{tabular}{|c|c|c|c|c|c|c|c|}
\hline \multirow{2}{*}{ Source } & \multirow{2}{*}{$\begin{array}{c}\text { Soil depth } \\
(\mathrm{cm})\end{array}$} & \multicolumn{2}{|c|}{$\mathrm{Ng} \mathrm{kg}^{-1}$} & \multicolumn{2}{|c|}{$\mathrm{P} \mathrm{mg} \mathrm{kg}^{-1}$} & \multicolumn{2}{|c|}{$\mathrm{K} \mathrm{mg} \mathrm{kg}^{-1}$} \\
\hline & & $\mathrm{CT}$ & NT & $\mathrm{CT}$ & NT & $\mathrm{CT}$ & NT \\
\hline \multirow{2}{*}{ Malecka et al. (2012) } & $0-5$ & 0.96 & 1.12 & 2.09 & 1.92 & 149 & 225 \\
\hline & $10-20$ & 0.94 & 0.88 & 2.06 & 2.15 & 142 & 120 \\
\hline Moussa-Machraoui et al. (2010) & - & 1.08 & 1.75 & 2.86 & 4.86 & 316 & 377 \\
\hline \multirow{2}{*}{ López-Fando and Pardo (2009) } & $0-5$ & 0.72 & 1.14 & 1.8 & 2.3 & 280 & 370 \\
\hline & $5-10$ & 0.70 & 0.86 & 1.8 & 2.2 & 250 & 310 \\
\hline Gangwar et al. (2004) & - & 1.34 & 1.36 & 3.34 & 3.20 & 156 & 155 \\
\hline \multirow{2}{*}{ Iqbal et al. (2002) } & $0-15$ & 0.65 & 0.61 & 1.51 & 1.36 & 132 & 121 \\
\hline & $15-30$ & 0.59 & 0.57 & 1.2 & 1.22 & 122 & 113 \\
\hline
\end{tabular}




\section{TILLAGE SYSTEM AND CROP RESIDUES EFFECT ON CROP GROWTH AND PRODUCTION}

In sustainable crop production system, retention of crop residues is recommended for subsistence use of soil resources. To do so, conservation tillage for different arable crops is found most effective. Zero tillage with crop residue retention in the field is the most suitable technique for higher crop production than CT without crop residue retention. Results from several studies showed that wheat yield under different tillage systems were 27 to $31 \%$ greater in no-till and minimum tillage than $\mathrm{CT}$ (Table 8) (Hemmat \& Eskandari 2004). Crop yield was found to be significantly influenced by tillage system and in some studies it was recorded higher in ZT than $\mathrm{CT}$, however, different quality characters like protein contents were higher in CT. Zero tillage gives the yield and yield component equal to deep tillage but greater than traditional tillage (Govaerts et al. 2005). Zero tillage along with straw mulch adoption techniques increased the soil moisture ability, which was helpful for plants during dry season (Hemmat \& Eskandari 2006). Although crop residue reduced the $30 \%$ seed emergence initially if seeds were in contact with crop residues; however, subsequent moisture availability helped seeds imbibition. Seed emergence was increased when seed was placed at proper soil depth and crop residues present at soil surface acting as mulch and reducing the evaporation losses (Morris et al. 2009). Conventional tillage practices reduced 90 to $100 \%$ presence of crop residues at soil surface as compared to reduced tillage $(50-70 \%)$. No-till facilitates make a check for soil erosion losses as result of accumulation of crop residues (López-Bellido et al. 2003). In rice-wheat system, a common practice for management of rice or wheat residues is burning these into the field. Although it is the easiest way to get rid of residues, as a few tillage operations for seedbed preparation are reduced. Similarly, some weed species, other pest and disease incidence are curtailed, nonetheless, burning exerted detrimental effects to induce soil erosion. The soil loss from the burn/low-till was similar to conventionally managed fields (McCool et al. 2008). Retention of previous crop stubbles help to conserve soil resources in terms of moisture, organic matter, nutrients, and some friendly insect species. No-till technique is most suitable in those areas where rainfall is less and are facing problem of less soil water availability (De Vita et al. 2007). Another benefit of ZT, which has much importance for plant growth, is low temperature of upper soil. Lower soil temperature is helpful in retaining organic matter within soil. However, it also delayed the seedling emergence and a revival of seedling from 1-3 and 4-5 days later than in CT was observed (Qin et al. 2008). In conventional system, the main cause of low yield of wheat is delayed planting which is due to late maturing fine rice cultivars. Wheat production after rice was higher at reduced tillage along with crop residues incorporation along with nitrogen (Gangwar et al. 2006). Sustainable crop production and improved soil physical environment can be achieved by retaining crop residues along with NT. Rice-wheat cropping system removes $\mathrm{N}, \mathrm{P}$ and $\mathrm{K}$ more than 300,30 and $300 \mathrm{~kg} \mathrm{ha}^{-1}$, respectively, from the soil profile. Removal of rice residues controls the outbreak of deleterious pest, and residues burning causes huge losses of $\mathrm{N}$ (up to $80 \%$ ), P (25\%), K (21\%), and S (4-60\%), air pollution and organic matter while incorporation of residues maintain the sustainability of soil. Residues incorporation caused immobilization of inorganic $\mathrm{N}$ that was overcut by using $\mathrm{N}$ as starter dose and wheat yield was not affected due to $\mathrm{N}$ immobilization. Rice residues retaining at the soil surface enhanced the $\mathrm{NO}_{3}$ by $46 \%, \mathrm{~N}$ uptake by $29 \%$, and yield by $37 \%$ greater than burning. Rice residues not only affects soil physical properties but also had transformed the electrochemical properties of acid soil that reduces the $\mathrm{P}$ fixation. Residues retaining and incorporation had positive effect on wheat yield than burning and removal (Malhi \& Lemke 2007). Zero tillage along with rice crop residues retaining at the surface not only accumulated organic matter but also enhanced the microbial biomass and mineralization (Sparrow et al. 2006). Intensive agriculture system caused the soil erosion and fertility problems. ZT along with crop residues increased the crop yields, microbial activity, nutrient availability, and reduced the soil erosion (Govaerts et al. 2007). Deep tillage and no till gave equal and higher grain yield, total yield, water use efficiency than off-set disk and sub-surface tillage systems (Mrabet 2002; Rafi et al. 2012). 
TABLE 8. Tillage systems effects on wheat grain yield in puddled rice field

\begin{tabular}{lccccc}
\hline \multirow{2}{*}{ Source } & Years & \multicolumn{4}{c}{ Wheat grain yield (Mg ha-1 } \\
\cline { 3 - 6 } & & $\mathrm{NT}$ & $\mathrm{CT}$ & Yield gain & Gain \% \\
\hline Prasad et al. (2002) & 2 & 4.1 & 3.4 & 0.7 & 20.6 \\
Singh (2010) & 2 & 3.7 & 3.8 & -0.1 & -2.7 \\
Gill (2006) & 2 & 2.6 & 2.4 & 0.2 & 8.3 \\
Husnjak et al. (2002) & 2 & 5.7 & 5.6 & 0.1 & 1.8 \\
Huang et al. (2012) & 2 & 7.0 & 6.4 & 0.6 & 9.4 \\
De Vita et al. (2007) & 3 & 4.0 & 4.5 & -0.5 & -12.5 \\
Usman et al. (2010) & 2 & 5.6 & 5.5 & 0.1 & 1.8 \\
Ozpinar (2006) & 2 & 4.6 & 4.4 & 0.2 & 4.5 \\
Gangwar et al. (2006) & 3 & 4.8 & 4.6 & 0.2 & $4.3 \mathrm{c}$ \\
Cociu and Alionte (2011) & 2 & 5.6 & 5.5 & 0.1 & 1.8 \\
Rafi et al. (2012) & 2 & 5.2 & 4.4 & 0.8 & 18.1 \\
Yadav et al. (2002) & 2 & 3.6 & 3.2 & 0.4 & 12.5 \\
\hline
\end{tabular}

\section{TILLAGE SYSTEM AND FARM ECONOMICS}

An important constraint of conventional tillage system is huge consumption of fuel, which ultimately reduce the net profit from unit area. Zero tillage is found to be cost effective by reducing use of fuel consuming machinery. Moreover, ZT reduces the risk of global warming due to less emission of fuel carbon and residue burning (Hobbs 2001). Zero tillage technology is renowed as a resource saving technology due to saving of time, cost of production and irrigation. Zero tillage gave the maximum net return and benefit cost ratio; a result of decreased unwise tillage operations and labor charges. More than $100 \mathrm{M}$ ha area of the world is under ZT and this increase in convention of $\mathrm{ZT}$ is due to economics of crop production (Verch et al. 2009). The direct drilling and conventional planting method for sowing wheat obtained average net income per acre of direct drilled plots at US\$93, whereas, for conventional plots was US\$74 per acre. Those farmers practicing ZT received an additional net income of US\$19 (26\%) over the conventional cultivated plots (DGA 2000). The adoption of ZT depended upon different factors like climatic conditions, soil characteristics, cropping pattern and overall farming operations (Uri 2000). Conservation agriculture minimized the energy consumption, workloads of farm operations in the range of $15-50 \%$, and enhanced the energetic productivity by $25-100 \%$ (Garcua-Torres 2000). The farmers are preferring to purchase or adoption of ZT planters/drills due to less cost of production as compared to CT (Landers 2000). The wheat acreage with ZT technology increased rapidly in the rice-wheat zone because of more benefits of ZT in terms of water, fertilizer and other agricultural resources. In addition, there were no sufficient evidences about the drastic weeds infestation in the ZT. This technology also reduced the per capita cost of production, which ultimately gave higher farm profit (Iqbal et al. 2002). Zero tillage is often called the resource saving technique due to saving of time, cost of production and water. However, in case of Punjab, Pakistan, the main reason of adoption of ZT is not saving water or natural resources but economic benefits of wheat cultivation with ZT (Erenstein et al. 2008b). It is estimated that about $13.5 \mathrm{M}$ ha area was under rice-wheat cropping system in the Indo-Gangetic Plains which might had a vital role to overcome the problem of food security, but due to frequent tillage operation, high cost of crop production with imbalanced use of inputs, this system is not remained economic. However, by using ZT in this system had proven its ability. The yield of ZT wheat either higher or equal to CT but ZT wheat was remained $6 \%$ more economical than CT (Saharawat et al. 2010).

\section{CONCLUSION}

A cropping system is an opportunity for the farmers to help them in decision making in an ever-changing 
environmental condition in agriculture to remain sustainable. Rice-wheat cropping system has its importance in over the world's agriculture. Coping demands to food security, farmers of this cropping system will have to increase food from fewer resources while sustaining environmental quality. ZT is one technology that fits this need and is being rapidly adopted in the IGP in wheat after rice. The present study has reviewed and provides plenty of unique information in relation to $\mathrm{ZT}$ in the rice-wheat systems of the IGP. Although the various sources differed in rigor and detail, but same consistent messages come through. The combined effect of a yield increase with a cost saving implies that returns to ZT adoption are robust, thereby, significantly reducing the risk of adoption. Still, significant knowledge gaps exist. Most of the studies focus on either the plot level or the macro-level. Gaining a better understanding of the intermediate levels and potential interactions is needed to assess the degree to which the gains are actually realized on the ground and the scope for scaling up from plot-level impacts. Most studies report on the technical and private financial gains of ZT at plot level with limited documentation of socioeconomic, livelihood, and environmental impacts. Addressing these knowledge gaps would significantly strengthen our understanding of ZT impacts in the IGP and its scaling-out potential. In rice-wheat system, zero tillage not only reduced the cost of production but also enhanced the net income and wheat yield. Zero tillage has economic advantage over conventional tillage system. Zero tillage primarily has a positive environmental impact (savings of fossil fuel, reduced emissions of greenhouse gas, water savings), and this would enhance the social returns to the research and development investment. The popularity of the zero-tillage technology is resource saving, increase crop production and improve soil physical properties. In rice-wheat system, rice stubbles act as mulch, which reduced the weed density, soil erosion and overcome the water storage.

\section{ACKNOWLEDGEMENTS}

Authors greatly acknowledge the financial support by the Higher Education Commission of Pakistan.

\section{REFERENCES}

Abid, M. \& Lal, R. 2008. Tillage and drainage impact on soil quality: I. Aggregate stability, carbon and nitrogen pools. Soil and Tillage Research 100(1-2): 89-98.

Addiscott, T.M. \& Thomas, D. 2000. Tillage, mineralization and leaching: Phosphate. Soil and Tillage Research 53(3-4): 255-273.
Ahmad, A., Ashfaq, M., Rasul, G., Wajid, S.A., Khaliq, T., Rasul, F., Saeed, U., Rahman, M.H.U., Hussain, J., Ahmad Baig, I. \& Naqvi, S.A.A. 2015. Impact of climate change on the rice-wheat cropping system of Pakistan. In Handbook of Climate Change and Agroecosystems: The Agricultural Model Intercomparison and Improvement Project Integrated Crop and Economic Assessments, Part 2. Singapore: World Scientific pp. 219-258.

Ahmad, M., Ilyas, M. \& Turral, H. 2004. A comparative analysis of crop water productivity of rice-wheat and cottonwheat rotations in Rechna Doab, Punjab, Pakistan. In New Directions for a Diverse Planet, 4th International Crop Science Congress in conjunction with the 12th Australian Agronomy Conference and the 5th Asian Crop Science Conference. Brisbane: Australian Society of Agronomy.

Ahmad, N., Hassan, F.U. \& Belford, R.K. 2009. Effect of soil compaction in the sub-humid cropping environment in Pakistan on uptake of NPK and grain yield in wheat (Triticum aestivum): I. Compaction. Field Crops Research 110(1): 54-60.

Al-Kaisi, M.M., Yin, X. \& Licht, M.A. 2005. Soil carbon and nitrogen changes as influenced by tillage and cropping systems in some Iowa soils. Agriculture, Ecosystems \& Environment 105(4): 635-647.

Alvarez, R. \& Steinbach, H.S. 2009. A review of the effects of tillage systems on some soil physical properties, water content, nitrate availability and crops yield in the Argentine Pampas. Soil and Tillage Research 104(1): 1-15.

Bai, Y., Chen, F., Li, H., Chen, H., He, J., Wang, Q., Tullberg, J.N. \& Gong, Y. 2008. Traffic and tillage effects on wheat production on the Loess Plateau of China: 2. Soil physical properties. Soil Research 46(8): 652-658.

Bakhsh, K., Hassan, I. \& Maqbool, A. 2005. Impact assessment of zero-tillage technology in rice-wheat system: A case study from Pakistani Punjab. Electronic Journal of Environmental, Agricultural and Food Chemistry 4(6): 1132-1137.

Balesdent, J., Chenu, C. \& Balabane, M. 2000. Relationship of soil organic matter dynamics to physical protection and tillage. Soil and Tillage Research 53(3-4): 215-230.

Basamba, T.A., Amezquita, E., Singh, B.R. \& Rao, I.M. 2006. Effects of tillage systems on soil physical properties, root distribution and maize yield on a Colombian acid-savanna Oxisol. Acta Agriculturae Scandinavica Section B-Soil and Plant Science 56(4): 255-262.

Bauer, P.J., Frederick, J.R. \& Busscher, W.J. 2002. Tillage effect on nutrient stratification in narrow-and wide-row cropping systems. Soil and Tillage Research 66(2): 175-182.

Bescansa, P., Imaz, M.J., Virto, I., Enrique, A. \& Hoogmoed, W.B. 2006. Soil water retention as affected by tillage and residue management in semiarid Spain. Soil and Tillage Research 87(1): 19-27.

Boydaş, M.G. \& Turgut, N. 2007. Effect of tillage implements and operating speeds on soil physical properties and wheat emergence. Turkish Journal of Agriculture and Forestry 31(6): 399-412. 
Brula, M.I. 2002. Zero tillage catalyst to economical production. Agro Veterinary News 14(5): 1-14.

Carr, P.M., Horsley, R.D. \& Poland, W.W. 2003. Tillage and seeding rate effects on wheat cultivars. Crop Science 43(1): 210-218.

Cavalieri, K.M.V., da Silva, A.P., Tormena, C.A., Leão, T.P., Dexter, A.R. \& Håkansson, I. 2009. Long-term effects of no-tillage on dynamic soil physical properties in a Rhodic Ferrasol in Paraná, Brazil. Soil and Tillage Research 103(1): 158-164.

Cociu, A.I. \& Alionte, E. 2011. Yield and some quality traits of winter wheat, maize and soybean, grown in different tillage and deep loosening systems aimed to soil conservation. Romanian Agricultural Research 28(1): 109120.

Czyż, E.A. \& Dexter, A.R. 2008. Soil physical properties under winter wheat grown with different tillage systems at selected locations. International Agrophysics 22(3): 191-201.

da Silveira Nicoloso, R., Amado, T.J.C., Schneider, S., Lanzanova, M.E., Girardello V.C. \& Bragagnolo, J. 2008. Eficiência da escarificação mecânica e biológica na melhoria dos atributos físicos de um latossolo muito argiloso e no incremento do rendimento de soja. R. Bras. Ci. Solo 32: 1723-1734.

De Moraes Sa, J.C., Cerri, C.C., Lal, R., Dick, W.A., de Cassia Piccolo, M. \& Feigl, B.E. 2009. Soil organic carbon and fertility interactions affected by a tillage chronosequence in a Brazilian Oxisol. Soil and Tillage Research 104(1): 56-64.

De Vita, P., Di Paolo, E., Fecondo, G., Di Fonzo, N. \& Pisante, M. 2007. No-tillage and conventional tillage effects on durum wheat yield, grain quality and soil moisture content in southern Italy. Soil and Tillage Research 92(1-2): 69-78.

Deen, W. \& Kataki, P.K. 2003. Carbon sequestration in a long-term conventional versus conservation tillage experiment. Soil and Tillage Research 74(2): 143-150.

Derpsch, R., Friedrich, T., Kassam, A. \& Li, H. 2010. Current status of adoption of no-till farming in the world and some of its main benefits. International Journal of Agricultural and Biological Engineering 3(1): 1-25.

DGA. 2000. Resource Conservation Technology for Enhancing Wheat Productivity. Recommendations for 2000-01. Punjab: Directorate General Agriculture (DGA).

Erenstein, O. \& Laxmi, V. 2008. Zero tillage impacts in India's rice-wheat systems: A review. Soil and Tillage Research 100(1-2): 1-14.

Erenstein, O., Sayre, K., Wall, P., Dixon, J. \& Hellin, J. 2008a. Adapting no-tillage agriculture to the conditions of smallholder maize and wheat farmers in the tropics and subtropics. In No-till Farming Systems, edited by Goddard, T., Zoebisch, M., Gan, Y., Ellis, W., Watson, A. \& Sombatpanit, S. World Association of Soil and Water Conservation (WASWC). pp. 253-278.

Erenstein, O., Farooq, U., Malik, R.K. \& Sharif, M. 2008b. Onfarm impacts of zero tillage wheat in South Asia's rice-wheat systems. Field Crops Research 105(3): 240-252.
Fabrizzi, K.P., Garcia, F.O., Costa, J.L. \& Picone, L.I. 2005. Soil water dynamics, physical properties and corn and wheat responses to minimum and no-tillage systems in the southern Pampas of Argentina. Soil and Tillage Research 81(1): 57-69.

Fernández, R.O., Fernández, P.G., Cervera, J.G. \& Torres, F.P. 2007. Soil properties and crop yields after 21 years of direct drilling trials in southern Spain. Soil and Tillage Research 94(1): 47-54.

Fernández-Ugalde, O., Virto, I., Bescansa, P., Imaz, M.J., Enrique, A. \& Karlen, D.L. 2009. No-tillage improvement of soil physical quality in calcareous, degradation-prone, semiarid soils. Soil and Tillage Research 106(1): 29-35.

Ferreras, L.A., Costa, J.L., Garcia, F.O. \& Pecorari, C. 2000. Effect of no-tillage on some soil physical properties of a structural degraded Petrocalcic Paleudoll of the southern "Pampa" of Argentina. Soil and Tillage Research 54(1-2): 31-39.

Gangwar, K.S., Singh, K.K., Sharma, S.K. \& Tomar, O.K. 2006. Alternative tillage and crop residue management in wheat after rice in sandy loam soils of Indo-Gangetic plains. Soil and Tillage Research 88(1-2): 242-252.

Gangwar, K.S., Singh, K.K. \& Sharma, S.K. 2004. Effect of tillage on growth, yield and nutrient uptake in wheat after rice in the Indo-Gangetic Plains of India. The Journal of Agricultural Science 142(4): 453-459.

Garcua-Torres, L. 2000. Conservation tillage in Europe: A needed challenge. Conservation Tillage: A Viable Option for Sustainable Agriculture in Central Asia, edited by Karabayev, M., Satybaldin, A., Benites, J.R., Friedrich, T., Pala, M. \& Payne, T. Almaty, Kazakhstan: CIMMYT; Aleppo, Syria: ICARDA. pp. 46-49.

Gill, M.A. 2006. Zero tillage wheat production in rice-wheat cropping system: Evidence from farmers' field. Pakistan Journal of Agricultural Research 19(4): 1-6.

Govaerts, B., Mezzalama, M., Unno, Y., Sayre, K.D., LunaGuido, M., Vanherck, K., Dendooven, L. \& Deckers, J. 2007. Influence of tillage, residue management, and crop rotation on soil microbial biomass and catabolic diversity. Applied Soil Ecology 37(1-2): 18-30.

Govaerts, B., Sayre, K.D. \& Deckers, J. 2005. Stable high yields with zero tillage and permanent bed planting? Field Crops Research 94(1): 33-42.

Gupta, R.K., Naresh, R.K., Hobbs, P.R., Jiaguo, Z. \& Ladha, J.K. 2003. Sustainability of post green Revolution agriculture: The rice wheat cropping systems of the Indo gangetic plains and China. In Improving the Productivity and Sustainability of Rice-Wheat Systems: Issues and Impacts, edited by Ladha, J.K., Hill, J.E., Duxbyry, J.M., Gupta, R.K. \& Buresh, R.J. New Jersey: John Wiley \& Sons, Inc. pp.1-25.

Håkansson, I. 2005. Machinery-Induced Compaction of Arable Soils. Uppsala: Institutionen för markvetenskap, Avdelningen för jordbearbetning.

Hamza, M.A. \& Anderson, W.K. 2005. Soil compaction in cropping systems: A review of the nature, causes and possible solutions. Soil and Tillage Research 82(2): 121-145. 
Hemmat, A. \& Eskandari, I. 2004. Conservation tillage practices for winter wheat-fallow farming in the temperate continental climate of northwestern Iran. Field Crops Research 89(1): 123-133.

Hemmat, A. \& Eskandari, I. 2006. Dryland winter wheat response to conservation tillage in a continuous cropping system in northwestern Iran. Soil and Tillage Research 86(1): 99-109.

Hernanz, J.L., Sánchez-Girón, V. \& Navarrete, L. 2009. Soil carbon sequestration and stratification in a cereal/ leguminous crop rotation with three tillage systems in semiarid conditions. Agriculture, Ecosystems \& Environment 133(12): $114-122$.

Hobbs, P.R. 2001. Tillage and crop establishment in south Asian rice-wheat systems: Present practices and future options. Journal of Crop Production 4(1): 1-22.

Hobbs, P.R. \& Gupta, R.K. 2003. Resource-conserving technologies for wheat in the rice-wheat system. In Improving the Productivity and Sustainability of Rice-Wheat Systems: Issues and Impacts, edited by Ladha, J.K., Hill, J.E., Duxbyry, J.M., Gupta, R.K. \& Buresh, R.J. New Jersey: John Wiley \& Sons, Inc. pp. 149-171.

Huang, G.B., Qiang, C.H.A.I., Feng, F.X. \& Yu, A.Z. 2012. Effects of different tillage systems on soil properties, root growth, grain yield, and water use efficiency of winter wheat (Triticum aestivum L.) in arid Northwest China. Journal of Integrative Agriculture 11(8): 1286-1296.

Husnjak, S., Filipovic, D. \& Kosutic, S. 2002. Influence of Different Tillage Systems On Soil Physical Properties and Crop Yield. Czech Republic: Rostlinna Vyroba-UZPI. pp. 249-254.

Iqbal, M., Khan, M.A., Anwar, M.Z. \& Mohsin, A.Q. 2002. Zerotillage technology and farm profits: A case study of wheat growers in the rice zone of Punjab. The Pakistan Development Review 41(4): 665-682.

Jacobs, A., Rauber, R. \& Ludwig, B. 2009. Impact of reduced tillage on carbon and nitrogen storage of two Haplic Luvisols after 40 years. Soil and Tillage Research 102(1): 158-164

Jat, M.L., Gathala, M.K., Ladha, J.K., Saharawat, Y.S., Jat, A.S., Kumar, V., Sharma, S.K., Kumar, V. \& Gupta, R. 2009. Evaluation of precision land leveling and double zero-till systems in the rice-wheat rotation: Water use, productivity, profitability and soil physical properties. Soil and Tillage Research 105(1): 112-121.

Jin, H., Hongwen, L., Xiaoyan, W., McHugh, A.D., Wenying, L., Huanwen, G. \& Kuhn, N.J. 2007. The adoption of annual subsoiling as conservation tillage in dryland maize and wheat cultivation in northern China. Soil and Tillage Research 94(2): 493-502.

Khaledian, M.R., Mailhol, J.C., Ruelle, P., Mubarak, I. \& Perret, S. 2010. The impacts of direct seeding into mulch on the energy balance of crop production system in the SE of France. Soil and Tillage Research 106(2): 218-226.
Khurshid, K.A.S.H.I.F., Iqbal, M., Arif, M.S. \& Nawaz, A. 2006. Effect of tillage and mulch on soil physical properties and growth of maize. International Journal of Agriculture and Biology 8(5): 593-596.

Koch, H.J. \& Stockfisch, N. 2006. Loss of soil organic matter upon ploughing under a loess soil after several years of conservation tillage. Soil and Tillage Research 86(1): 73-83.

Kukal, S.S. \& Aggarwal, G.C. 2003. Puddling depth and intensity effects in rice-wheat system on a sandy loam soil: I. development of subsurface compaction. Soil and Tillage Research 72(1): 1-8.

Kumar, A. \& Yadav, D.S. 2001. Long-term effects of fertilizers on the soil fertility and productivity of a rice-wheat system. Journal of Agronomy and Crop Science 186(1): 47-54.

Ladha, J.K., Dawe, D., Pathak, H., Padre, A.T., Yadav, R.L., Singh, B., Singh, Y., Singh, Y., Singh, P., Kundu, A.L. \& Sakal, R. 2003. How extensive are yield declines in long-term rice-wheat experiments in Asia? Field Crops Research 81(23): $159-180$

Ladha, J.K., Fischer, K.S., Hossain, M., Hobbs, P.R. \& Hardy, B. 2000. Improving the Productivity and Sustainability of RiceWheat Systems of the Indo-Gangetic Plains: A synthesis of NARS-IRRI Partnership Research. Los Baños: International Rice Research Institute.

Landers, J. 2000. Twenty-five practical lessons learned for implementation of zero tillage in Brazil. In Conservation Tillage: A Viable Option for Sustainable Agriculture in Central Asia. Almaty, Kazakhstan: CIMMYT; Aleppo, Syria: ICARDA.

Licht, M.A. \& Al-Kaisi, M. 2005. Strip-tillage effect on seedbed soil temperature and other soil physical properties. Soil and Tillage Research 80(1-2): 233-249.

Lithourgidis, A.S., Tsatsarelis, C.A. \& Dhima, K.V. 2005. Tillage effects on corn emergence, silage yield, and labor and fuel inputs in double cropping with wheat. Crop Science 45(6): 2523-2528.

Liu, C.A., Jin, S.L., Zhou, L.M., Jia, Y., Li, F.M., Xiong, Y.C. \& Li, X.G. 2009. Effects of plastic film mulch and tillage on maize productivity and soil parameters. European Journal of Agronomy 31(4): 241-249.

Li, Su-Juan, Chen, J-K., Chen, F., Li, L. \& Zhang, H.L. 2008. Characteristics of growth and development of winter wheat under zero tillage in North China Plain. Acta Agronomica Sinica 34(2): 290-296.

Logsdon, S.D. \& Karlen, D.L. 2004. Bulk density as a soil quality indicator during conversion to no-tillage. Soil and Tillage Research 78(2): 143-149.

López-Bellido, R.J., López-Bellido, L., Castillo, J.E. \& LópezBellido, F.J. 2003. Nitrogen uptake by sunflower as affected by tillage and soil residual nitrogen in a wheat-sunflower rotation under rainfed Mediterranean conditions. Soil and Tillage Research 72(1): 43-51. 
López-Fando, C. \& Pardo, M.T. 2009. Changes in soil chemical characteristics with different tillage practices in a semi-arid environment. Soil and Tillage Research 104(2): 278-284.

Lupwayi, N.Z., Clayton, G.W., O’Donovan, J.T., Harker, K.N., Turkington, T.K. \& Soon, Y.K. 2006. Nitrogen release during decomposition of crop residues under conventional and zero tillage. Canadian Journal of Soil Science 86(1): 11-19.

Malecka, I., Blecharczyk, A., Sawinska, Z. \& Dobrzeniecki, T. 2012. The effect of various long-term tillage systems on soil properties and spring barley yield. Turkish Journal of Agriculture and Forestry 36(2): 217-226.

Malhi, S.S. \& Lemke, R. 2007. Tillage, crop residue and N fertilizer effects on crop yield, nutrient uptake, soil quality and nitrous oxide gas emissions in a second 4-yr rotation cycle. Soil and Tillage Research 96(1-2): 269-283.

Martínez, E., Fuentes, J.P., Silva, P., Valle, S. \& Acevedo, E. 2008. Soil physical properties and wheat root growth as affected by no-tillage and conventional tillage systems in a Mediterranean environment of Chile. Soil and Tillage Research 99(2): 232-244.

Martin-Rueda, I., Munoz-Guerra, L.M., Yunta, F., Esteban, E., Tenorio, J.L. \& Lucena, J.J. 2007. Tillage and crop rotation effects on barley yield and soil nutrients on a Calciortidic Haploxeralf. Soil and Tillage Research 92(1-2): 1-9.

McConkey, B.G., Liang, B.C., Campbell, C.A., Curtin, D., Moulin, A., Brandt, S.A. \& Lafond, G.P. 2003. Crop rotation and tillage impact on carbon sequestration in Canadian prairie soils. Soil and Tillage Research 74(1): 81-90.

McCool, D.K., Pannkuk, C.D., Kennedy, A.C. \& Fletcher, P.S. 2008. Effects of burn/low-till on erosion and soil quality. Soil and Tillage Research 101(1-2): 2-9.

McMaster, G.S., Palic, D.B. \& Dunn, G.H. 2002. Soil management alters seedling emergence and subsequent autumn growth and yield in dryland winter wheat-fallow systems in the central Great Plains on a clay loam soil. Soil and Tillage Research 65(2): 193-206.

Meenakshi. 2010. Influence of paddy residue and nitrogen management on the productivity of wheat (Triticum aestivum L.). Master Thesis. Ludhiana: Punjab Agricultural University (Unpublished).

Morris, N.L., Miller, P.C.H., Orson, J.H. \& Froud-Williams, R.J. 2009. The effect of wheat straw residue on the emergence and early growth of sugar beet (Beta vulgaris) and oilseed rape (Brassica napus). European Journal of Agronomy 30(3): 151-162.

Moussa-Machraoui, S.B., Errouissi, F., Ben-Hammouda, M. \& Nouira, S. 2010. Comparative effects of conventional and no-tillage management on some soil properties under Mediterranean semi-arid conditions in northwestern Tunisia. Soil and Tillage Research 106(2): 247-253.

Mrabet, R. 2002. Stratification of soil aggregation and organic matter under conservation tillage systems in Africa. Soil and Tillage Research 66(2): 119-128.
Mrabet, R., Ibno Namr, K., Smali, N., Ahdi, M. \& Saber, N. 2000. Soil quality and associated changes in fertilizer management for wheat in no-tillage production systems of semiarid Morocco. In Actes du Premier Congrès de l'Association Marocaine des Sciences du Sol. Meknès: Ecole nationale de l'agriculture de Meknès. pp. 18-19.

Osunbitan, J.A., Oyedele, D.J. \& Adekalu, K.O. 2005. Tillage effects on bulk density, hydraulic conductivity and strength of a loamy sand soil in southwestern Nigeria. Soil and Tillage Research 82(1): 57-64.

Ozpinar, S. 2006. Effects of tillage systems on weed population and economics for winter wheat production under the Mediterranean dryland conditions. Soil and Tillage Research 87(1): 1-8.

Pedrotti, A., Pauletto, E.A., Crestana, S., Holanda, F.S.R., Cruvinel, P.E. \& Vaz, C.M.P. 2005. Evaluation of bulk density of Albaqualf soil under different tillage systems using the volumetric ring and computerized tomography methods. Soil and Tillage Research 80(1-2): 115-123.

Prasad, B., Sinha, R.K. \& Singh, A.K. 2002. Studies on the effect of nitrogen management on yield of wheat in ricewheat cropping system under zero tillage. In Proceedings International Workshop Herbicide Resistance Management and Zero Tillage in Rice-Wheat Cropping System. pp. 4-6.

Qin, H.L., Gao, W.S., Ma, Y.C., Ma, L., Yin, C.M., Chen, Z. \& Chen, C. 2008. Effects of subsoiling on soil moisture under no-tillage for two years. Agricultural Sciences in China 7(1): $88-95$

Qingjie, W., Hao, C., Hongwen, L., Wenying, L., Xiaoyan, W., McHugh, A.D., Jin, H. \& Huanwen, G. 2009. Controlled traffic farming with no tillage for improved fallow water storage and crop yield on the Chinese Loess Plateau. Soil and Tillage Research 104(1): 192-197.

Rafi, Q., Riaz, A. \& Muhammad, I. 2012. Response of wheat to tillage and nitrogen fertilization in rice-wheat system. Pakistan Journal of Agricultural Sciences 49(3): 243-254.

Rahman, M.A., Chikushi, J., Saifizzaman, M. \& Lauren, J.G. 2005. Rice straw mulching and nitrogen response of no-till wheat following rice in Bangladesh. Field Crops Research 91(1): 71-81.

Rautaray, S.K. 2005. Machinery for conservation agriculture: Progress and needs. Conservation Agriculture-Status and Prospects, edited by Abrol, I.P., Gupta, R.K. \& Malik, R.K. New Delhi: Centre for Advancement of Sustainable Agriculture pp. 43-49.

Saharawat, Y.S., Singh, B., Malik, R.K., Ladha, J.K., Gathala, M., Jat, M.L. \& Kumar, V. 2010. Evaluation of alternative tillage and crop establishment methods in a rice-wheat rotation in North Western IGP. Field Crops Research 116(3): 260-267.

Sainju, U.M., Whitehead, W.F., Singh, B.P. \& Wang, S. 2006. Tillage, cover crops, and nitrogen fertilization effects on soil nitrogen and cotton and sorghum yields. European Journal of Agronomy 25(4): 372-382. 
Salinas-Garcıa, J.R., de J Velázquez-García, J., GallardoValdez, M., Diaz-Mederos, P., Caballero-Hernández, F., Tapia-Vargas, L.M. \& Rosales-Robles, E. 2002. Tillage effects on microbial biomass and nutrient distribution in soils under rain-fed corn production in central-western Mexico. Soil and Tillage Research 66(2): 143-152.

Selles, F., McConkey, B.G. \& Campbell, C.A. 1999. Distribution and forms of $\mathrm{P}$ under cultivator-and zero-tillage for continuous-and fallow-wheat cropping systems in the semiarid Canadian prairies. Soil and Tillage Research 51(1-2): 47-59.

Sharma, P.K. \& Bhushan, L. 2001. Physical characterization of a soil amended with organic residues in a rice-wheat cropping system using a single value soil physical index. Soil and Tillage Research 60(3-4): 143-152.

Sharma, R.K., Chhokar, R.S., Chauhan, D.S., Gathala, M.K., Rani, V. \& Kumar, A. 2002. Paradigm tillage shift in ricewheat system for greater profitability. In Herbicide Resistance Management and Zero Tillage in Rice-Wheat Cropping System. Hisar: CCSHAU. pp. 131-135.

Shipitalo, M.J., Dick, W.A. \& Edwards, W.M. 2000. Conservation tillage and macropore factors that affect water movement and the fate of chemicals. Soil and Tillage Research 53(3-4): 167-183.

Šimon, T., Javůrek, M., Mikanova, O. \& Vach, M. 2009. The influence of tillage systems on soil organic matter and soil hydrophobicity. Soil and Tillage Research 105(1): 44-48.

Singh, D. 2010. Studies to moderate the heat stress effects on wheat (Triticum aestivum L.) productivity. PhD Thesis. Ludhiana: Punjab Agricultural University (Unpublished).

Singh, K.K. \& Sharma, S.K. 2005. Conservation tillage and crop residue management in rice-wheat cropping system. In Conservation Agriculture-Status and Prospects, edited by Abrol, I.P., Gupta, R.K. \& Malik, R.K. New Delhi: Centre for Advancement of Sustainable Agriculture. pp. 23-32.

Sinha, R.K., Singh, A.K. \& Shahi, B. 2005. Need of Zero Tillage in Bihar: Farmer's Participatory Research. Haryana: Directorate of Extension Educatrion CCS Haryana Agricultural University Hisar-124 004. p. 261.

Sparrow, S.D., Lewis, C.E. \& Knight, C.W. 2006. Soil quality response to tillage and crop residue removal under subarctic conditions. Soil and Tillage Research 91(1-2): 15-21.

Sundermeier, A.P., Islam, K.R., Raut, Y., Reeder, R.C. \& Dick, W.A. 2011. Continuous no-till impacts on soil biophysical carbon sequestration. Soil Science Society of America Journal 75(5): 1779-1788.

Tabatabaeefar, A., Emamzadeh, H., Varnamkhasti, M.G., Rahimizadeh, R. \& Karimi, M. 2009. Comparison of energy of tillage systems in wheat production. Energy 34(1): 41-45.

Tahir, M.A., Sardar, M.S., Quddus, M.A. \& Ashfaq, M. 2008. Economics of zero tillage technology of wheat in ricewheat cropping system of Punjab-Pakistan. Journal of Animal and Plant Sciences 18: 42-46.

Teal, R.K., Freeman, K.W., Girma, K., Arnall, D.B., Lawles, J.W., Martin, K.L., Mullen, R.W. \& Raun, W.R. 2007. Effect of tillage and anhydrous ammonia application on nitrogen use efficiency of hard red winter wheat. Journal of Sustainable Agriculture 30(2): 51-67.

Thomas, G.A., Dalal, R.C. \& Standley, J. 2007. No-till effects on organic matter, $\mathrm{pH}$, cation exchange capacity and nutrient distribution in a Luvisol in the semi-arid subtropics. Soil and Tillage Research 94(2): 295-304.

Timsina, J. \& Connor, D.J. 2001. Productivity and management of rice-wheat cropping systems: Issues and challenges. Field Crops Research 69(2): 93-132.

Tripathi, R.P., Sharma, P. \& Singh, S. 2007. Influence of tillage and crop residue on soil physical properties and yields of rice and wheat under shallow water table conditions. Soil and Tillage Research 92(1-2): 221-226.

Uri, N.D. 2000. An evaluation of the economic benefits and costs of conservation tillage. Environmental Geology 39(34) $238-248$

Usman, K., Khalil, S.K., Khan, A.Z., Khalil, I.H. \& Khan, M.A. 2010. Tillage and herbicides impact on weed control and wheat yield under rice-wheat cropping system in Northwestern Pakistan. Soil and Tillage Research 110(1): 101-107.

Van Den Bossche, A., De Bolle, S., De Neve, S. \& Hofman, G. 2009. Effect of tillage intensity on $\mathrm{N}$ mineralization of different crop residues in a temperate climate. Soil and Tillage Research 103(2): 316-324.

Veiga, M.D., Reinert, D.J., Reichert, J.M. \& Kaiser, D.R. 2008. Short and long-term effects of tillage systems and nutrient sources on soil physical properties of a southern Brazilian Hapludox. Revista Brasileira de Ciência do Solo 32(4): 1437-1446.

Verch, G., Kächele, H., Höltl, K., Richter, C. \& Fuchs, C. 2009. Comparing the profitability of tillage methods in Northeas Germany-A field trial from 2002 to 2005. Soil and Tillage Research 104(1): 16-21.

Vogeler, I., Rogasik, J., Funder, U., Panten, K. \& Schnug, E. 2009. Effect of tillage systems and P-fertilization on soil physical and chemical properties, crop yield and nutrient uptake. Soil and Tillage Research 103(1): 137-143.

Wright, A.L. 2009. Phosphorus sequestration in soil aggregates after long-term tillage and cropping. Soil and Tillage Research 103(2): 406-411.

$\mathrm{Xu}$, T.P., Zhu, B., Wang, T. \& Kuang, F.H. 2006. Effects of returned straw on nutrient loss from slope cropland of purple soil. Journal of Soil and Water Conservation 20(1): 30-32.

Yadav, D.S., Sushant, A.R. \& Kumar, B. 2002. Performance of wheat under zero tillage in rice-wheat cropping system under Eastern UP conditions. In Proceedings of International Workshop on Herbicide Resistance Management and Zero Tillage in Rice-Wheat Cropping System. pp. 123-126.

Yaduraju, N.T. \& Mishra, J.S. 2002. Zero-Tillage in ricewheat cropping system on vertisols in Madhya Pradesh: Prospects and problems. In Proceedings of International Workshop on Herbicide Resistance Management and Zerotillage in Rice-Wheat Cropping System. pp. 4-6. 
Younis, M., Sabir, M., Iqbal, M. \& Alit, A. 2006. Comparative performance of zone till sowing, slot planting and conventional sowing technique of wheat in rice-vacated fields. Journal of Agricultural Research 44(1): 59-70.

Zamuner, E.C., Picone, L.I. \& Echeverria, H.E. 2008. Organic and inorganic phosphorus in Mollisol soil under different tillage practices. Soil and Tillage Research 99(2): 131-138.

Zhang, D.X., Han, Z.Q., Li, D.P., Liu, W., Gao, S., Hou, D. \& Chang, L. 2005. Effects of returning maize straw into field on dynamic change of soil microbial biomass $\mathrm{C}, \mathrm{N}$ and $\mathrm{P}$ under different promoted decay condition. The Journal of Applied Ecology 16(10): 1903-1908.

Zibilske, L.M., Bradford, J.M. \& Smart, J.R. 2002. Conservation tillage induced changes in organic carbon, total nitrogen and available phosphorus in a semi-arid alkaline subtropical soil. Soil and Tillage Research 66(2): 153-163.

Rafi Qamar*, Abdul Rehman, Muhammad Ehsan Safdar \& Hasnain Ali

Department of Agronomy

College of Agriculture

University of Sargodha

Pakistan
Atique ur Rehman \& Shakeel Ahmad

Department of Agronomy

Bahauddin Zakariya University

Multan

Pakistan

Hafiz Muhammad Rashad Javeed

Department of Environmental Sciences

COMSATS University Islamabad

Vehari Campus

Pakistan

*Corresponding author; email: rafi.qamar@uos.edu.pk

Received: 25 April 2020

Accepted: 8 October 2020 